the colonies, as in England, education was regarded as the concern of voluntary and privatelargely religious-enterprise. When the Government began to participate in education in the colonies (about I 833) it was mainly by the system of grants-in-aid. An important stage in the development of education in Africa was the publication of the report of the PhelpStokes Commission of Enquiry in I922. The report described the educational policies of governments and missions alike as inadequate and ' largely unreal as far as the vital needs of Africa are concerned '. This report, and that of a subsequent survey of education in East Africa carried out at the request of the British Government, profoundly influenced subsequent development; the principles recommended by the Commission were embodied in the Memorandum on Education in British Tropical Africa, published by the Colonial Office in 1925. In 1939 the Advisory Committee on Education in the Colonies was set up, its main task being to raise the educational standard of the mass of people; its second concern, to train a selected few for ' administrative and technical services as well as for positions of exceptional responsibilities'. During the war the Advisory Committee met frequently and published a number of reports on specific problems of education. The United Kingdom's Colonial Development and Welfare Acts (I940 and I945) made substantial funds available to colonial governments, but the greater part of these was used for capital costs, and the finance available for the expansion of primary education was limited. Nevertheless considerable progress was made-in fact, by 1952, so rapid was the development that the need was felt for a thorough re-examination of the principles of 1925 and a critical survey of the type of education provided and of its effects. A study was therefore made by two groups of experts, one in East and one in West Africa, and this was followed by a conference with representatives of educational bodies operating in Africa. The reports of the experts were presented, and the conference was held, in 1952; the resulting survey, African Education, 1953, represents the latest and most comprehensive attempt to find the answers to problems of education in Africa.

After a brief statement of policy and objectives, the publication under review discusses numerous problems arising in the application of educational policy in the dependencies. Such problems relate to the religious basis of education, questions of responsibility and control, the structure and organization of an educational system, teacher training, examinations, university education, education of women and girls, \&c. One section discusses limiting factors: local public opinion, language, and finance. A review of the present position (I954) in the various dependencies follows. The concluding section expresses the view that, though progress may seem to have been slow, and problems remain unsolved, 'the very strength and vociferation of local criticism is a tribute to the free growth of independent thought and speech under the system which has fostered it'. Useful figures on literacy and on expenditure on education, as well as analytical tables relating to students from dependencies studying in the United Kingdom, are given in appendixes.

\title{
Field research in Tanganyika
}

Dr. RoBert F. Gray, holding a Ford Foundation Fellowship, has just finished a survey of the Gorowa tribe of Mbulu District in Tanganyika. This tribe is related to the Iraqw recently studied by Mr. E. Winter, and Dr. Gray's survey was undertaken mainly for the purpose of comparing the two tribes. During his two-year fellowship Dr. Gray plans to make other short studies of three or four Tanganyika tribes, giving special attention to witchcraft and native medical practices.

\section{The Kenya History Society}

ReAders of Africa will be interested to know of the formation of the Kenya History Society in July of this year. The aims of the Society are stated to be the collection and pre- 